\title{
Moopa or barren: A rereading of the 1840 English-Setswana gospel of Luke 1:36-38 from a Setswana traditional practice
}

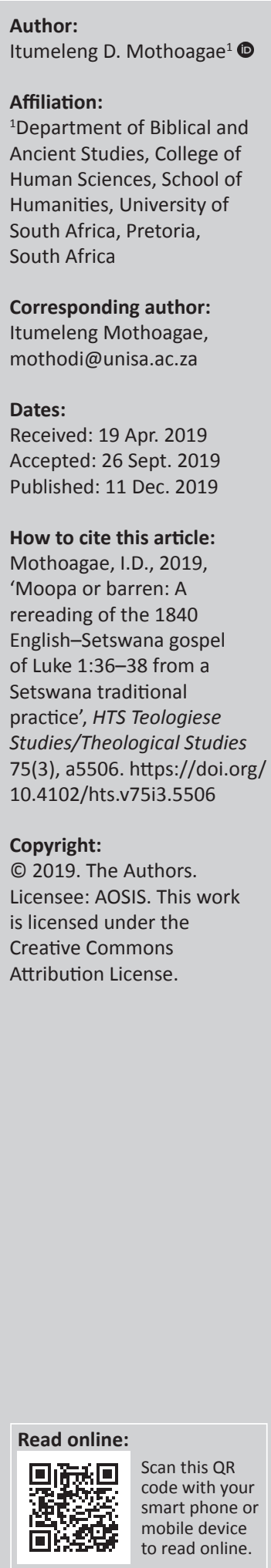

The 1840 gospel of Luke as translated by Moffat presents us with the cultural and imperial surveillance performed by a patriarchal system through the institutionalisation of motherhood and womanhood (bosadi). Motherhood or womanhood (bosadi) as a patriarchal institution has been a space in which patriarchal discursive practices have been realised through an act of politicising motherhood or womanhood. At the centre of this act of politicisation of motherhood or womanhood (bosadi) is the ability to carry and bear children (pelegi). The institution of motherhood or womanhood has facilitated a binary between motherhood (bosadi) and bareness (moopa). The womb/popelo as a symbol of fertility becomes the space of mothering women, of labelling, categorising and naming women that the system locates as moopa or barren. The article seeks to reread the narrative on childbearing in the 1840 gospel of Luke from a decolonial framework. I will argue that childbearing, as a patriarchal institution, has been a space in which the gaze of patriarchy has been produced to subjugate women through cultural and imperial masculinist gaze. I will also argue that there is a need to decolonise and liberate such a space (womb) as not a determinant of motherhood.

Keywords: motherhood; victimisation; barrenness; power; institution; storytelling; knowledge; wifehood; surveillance; patriarchy; decolonisation.

\section{Introduction}

The 1840 English-Setswana gospel of Luke was translated into a culture that was governed by its rules and norms. Luke 1:36-38 presents us with the tensions between the source text and the receptor culture (Setswana traditional practice). The dialogue between the angel and Mary regarding Elizabeth, like many other birth-prophesy narratives, brought to the fore the tension between the textual source and the oral (Setswana) traditional practice. The article seeks to argue that both of these sources can be located within the patriarchal or cultural (internal) and Western or imperial (external) of the masculinist surveillance. The Setswana practice of go thutafatsadirope (warming of the thighs) refers to the internal patriarchal form of surveillance and victimisation of the woman suspected of being infertile. Furthermore, motherhood as an institution of power and a social hierarchy within the space of wifehood has led to the labelling and stigmatisation of childless women. Similarly, the article engages the concept of barrenness in Luke 1:36-38 from the cultural hermeneutics paradigm. I will also argue in the article that the institutionalisation of motherhood as a performance of power resides in knowledge production. In other words, the stories of birth prophesy in the biblical texts are narrated by men. This is seen in the absence of a story that depicts the infertility of a man. Such stories one would argue are symptomatic of the masculinist gaze over the body of a woman. I will further state that African women literature on the very concept of motherhood is an attempt to depatriarchalise and redefine the discourse on motherhood, and to delink motherhood and victimhood. Above all, it is to make a distinction between wifehood and motherhood, by focusing on motherhood as an experience ('mothering') with its pains and rewards rather than motherhood as a patriarchal institution. I maintain that this approach is a form of decolonisation of motherhood.

\section{Childbearing in antiquity and the politicisation of the womb}

Dasen (2011) reflects on the fears of women within Greek and Roman marriages, stating that:

The birth of an heir was the principal aim of Greek and Roman marriages which, for strategic reasons, could legally take place as early as 12 years old for girls, especially in wealthy families and in urban contexts, despite the warnings of physicians (see Cox and Dixon, this volume). Many rituals aimed at

Note: The collection entitled 'Eben Scheffler Festschrift', sub-edited by Jurie H. le Roux (University of Pretoria) and Christo Lombaard (University of South Africa). 
promoting pregnancy and an easy delivery. Votive figurines of swaddled babies found in Greek as well as in Roman and Gallo-Roman sanctuaries were dedicated on various occasions; some may express the wish to have a child, if possible a boy (Miller Ammerman [2007]; De Cazanove [2008]). We do not know how long a young wife could wait before being suspected of infertility, which could be a cause of divorce. Families with one or two children, including at least a boy, seem to have represented an ideal (for example, Hesiod Works and Days 11.376-8; Pliny the Younger, Letters 4.15.3), attained, however, only through several offspring because of the low chances of survival to adulthood. (p. 296)

The eagerness to bear children, particularly male children, indicates the patriarchal gaze over the female body. Nnaemeka argues that such a gaze is both cultural and imperial (1997:6). Furthermore, the patriarchal invasion of the womb illustrates the gender politics of gazing. The biblical narratives of birth-prophecy stories illustrate the gender politics of surveillance performed through discursive practices constructed within the Judaic culture expressed in imperial mythologies. Put differently, women in the biblical narratives are presented as a symbol of infertility, based on the regimes of truths governing norms and cultural beliefs.

Through birth, they represent a symbol of fertility which comes at the intervention of the divine. Prayer and righteousness accompanied by unfailing faith in the divine dispels the categorisation of barrenness. Those that are barren or infertile are described and designated the terms such as 'cursed' and 'disfavoured'. In contrast, fertile women are designated the terms 'blessed' and 'favoured'. These categories create within the space of wifehood a social hierarchy occupied by those that the system regards as privileged.

Thus, motherhood then becomes a privilege and a distinguishing factor between a wife and a mother within the institution of marriage, because through motherhood, a wife gains a social status and recognition. The failure to have children is attributed to women and not to men, as men were believed to be carrying the seed that needs to be implanted into the womb of a woman. It is in such a belief system that failure to 'produce' resulted in a loss in familial and social status. It is in the two dimensions, namely social and religion, that we can observe the masculinist gaze and the imperial mythologies. In the next section, I will deal with storytelling as a performance of power.

\section{Storytelling as imperial: Performance of power in the gender construct}

Wire, reflecting on the biblical narratives of birth-prophesy stories, has argued convincingly that such mythological stories have for centuries influenced Christian discourse on the politics of pregnancy and motherhood (Wire 2005:71). She further argues that these stories offer an understanding of the 'assumptions, perspectives, and values' of the storytellers. The stories surrounding the birth prophecies highlight the key roles that women play in these stories. The stories provide us with valuable information about how pregnancy was perceived and about the social pressure on women to bear a boy child. Through storytelling, the narrator also performs hegemony in the construction of the discourse around pregnancy, birthing and motherhood. Put differently, the narrator determines the discourse and at the same time constructs knowledge around the institution of motherhood. It is worth noting that men are notably absent at the announcement of these birth-prophecy stories. In other words, the path to motherhood as an institution within the masculinist gaze is a discursive tool to perform disciplinary power.

These stories, according to Wire, play a fundamental role in underlining the role of women within the masculinist gaze (2005:72-91). Wire is of the opinion that there are 26 birth-prophecy stories, including the song of Hannah, Mary's song, the account of Rabbi Ishmael the High Priest, Elijah's birth prophecy, Zechariah's praise of God, an account of Miriam at Moses' birth and many others. These stories according to Wire fall within the long tradition of birth prophecy in ancient Israel, covering centuries before and after the time Jesus was born (2005:71).

In my opinion, these birth-prophesy stories do not only indicate a long ancient Israel tradition but also form part of the Greco-Roman world belief system. Roymans (2009:219-238) argues that this can be seen in the mythological depiction of the Roman hero and god Hercules, while in Greek mythology, there is a figure named Heracles who was the son of Zeus and the mortal Alcmene. Similarly, according to Silk, the story of Heracles reflects the intervention of the divine (1985:1-22).

Angels play a prominent role in these birth-prophesy stories. However, in Greek and Roman mythology, the gods themselves perform the act of impregnating. In the biblical narratives, the angels are sent to fulfil the prophetic message. In contrast with Greek and Roman mythology, the divine does not seem to be actively involved in the birthprophesy stories. While angels are technically sexless, the biblical depiction of angels such as Gabriel and Michael embodies the male figure. This is also seen in the iconographical traditions that portray angels as male. I would argue that the depiction of the angels as male illustrates the politics of motherhood as an institution governed and regulated by the masculinist gaze. These stories illustrate the imperial gaze based on the norms that regulate the 'regimes of truth' expressed in the religious belief system (Foucault 1991).

These stories highlight the performance of disciplinary power by the patriarchal social structure (Foucault 1978). The performance of such power removes women from the sacred space of the womb and places men within such a space, 
as those who determine the function and role of women as childbearers of particularly male children. Furthermore, as these stories were told, men aimed at performing power over female bodies. They also functioned as constructors of the institution of motherhood within the discursive practices of patriarchal gaze. Furthermore, the stories express women's fears and challenges. These include among others the possibility of not being able to bear children or of bearing a girl child instead of a boy child. They were expressing the fear of the unknown, which included the fear for the life of the newborn child. At the same time, these stories were also performing another level of power, that is, gender construction. In other words, motherhood is an institution that affords one entrance into a social hierarchy that is exclusively reserved for women who have borne children. Not only did these stories address the question of bareness or the fulfilment of prophecy, but they also performed disciplinary power in the construction of gender.

This is because, based on the politics of knowledge production in the Greco-Roman world, men occupied the space of producing written material. In other words, the scribes were predominantly men as they were provided with the opportunity to learn and to write. This form of privilege was not afforded to all persons.

Only the rich and powerful had this privilege. Moreover, as Foucault explains, storytelling is a form of power and surveillance (Foucault 1991:184-185) which I would argue means that the construction of gender was a form of power. It was a way of normalising and categorising sexual spaces in binary form (male and female). Furthermore, heterosexuality as a construction of gender was a space to contest for masculinity. Femininity then becomes a patriarchal space for normalisation of power and space. One of the things that gender construction has managed to do is to present us with the category 'woman'. This category has various markers, namely occupied, resistant, experienced and produced, through the processes of differentiation. Thus, to behave and act in a feminine manner is part of the dynamics of power within the institution of heterosexuality. Femininity then is a domain of power. Skeggs (2002) makes the following observation:

Femininity is the process through which women are gendered and become specific sorts of women. The process of becoming feminine ... occurs in the spaces of textually mediated discourse, in the dialectic between the active creating subject and the organization of her activity in and by texts, produced in the interests of a wider global market. (p. 98)

Based on the notion that gender construction is part of the processes of knowledge production, these stories functioned within the discourse of gender construction in facilitating textually mediated feminism as a site where values were allocated to women. A distinction between motherhood as an institution and motherhood as an experience is that through textually mediated stories, patriarchy constructs the institution of motherhood, allocating to women the values that should govern the site, constructs and appearance as a sign of value. The femininity of women who bear children is defined as ideal. As the most passive and dependent of femininities, such a form of femininity is coded as respectable and functions as a projection of male fantasies of the type of women they ought to be (Skeggs 2002:99). Nnaemeka (1997) states the following on the power dynamics of knowledge production:

Aware that gender construction is part of the processes of knowledge construction ... [we need to] locate storytelling at the heart of knowledge construction while recognizing the gender politics that often banishes storytelling to the periphery of 'real knowledge'. To a great extent, critics as knowledge producers and disseminators are also storytellers who are capable of creating not only new meanings but also new mythologies. (p. 7)

Put differently, these stories were an active form of subjectification, subjugation and the creation of agency through the institution of motherhood. Achebe (1976) makes the following argument on the power of storytelling when he states:

If you look at the world in terms of storytelling, you have, first of all, the man who agitates, the man who drums up the people I call him the drummer. Then you have the warrior, who goes forward and fights. But you also have the storyteller who recounts the event and this is one who survives, who outlives all the others. It is the storyteller, in fact, who makes us what we are, who creates history. The storyteller creates the memory that the survivors must have otherwise their surviving would have no meaning ... [The anthill survives] so that the new grass will have memory of the fire that devastated the savannah in the previous dry season. (pp. 131-45)

The observation by Achebe illustrates the power of the storyteller in the process of knowledge production. Motherhood as an institution needs to be understood within the broader framework of patriarchy. It is through the institution of motherhood that the masculinist gaze finds its actualisation. In other words, the notion of patriachalisation of motherhood needs to be located within the broader framework of the institution of patriarchy and power. Foucault contests the idea that people or groups exercise power by means of 'episodic' or 'sovereign' acts of domination or coercion; he perceives it rather as dispersed and pervasive. Power according to him is a kind of 'metapower' or 'regime of truth' that pervades society and it is in constant flux and negotiation. He employs the term 'power or knowledge' to imply that power is constituted through accepted forms of knowledge, scientific understanding and 'truth'. Thus, for Foucault, power is a form of multilaterality (Foucault 1978:63). Therefore, motherhood as a terrain of power is constructed as part of knowledge production. The body of a woman becomes an object and target of power. Through the institution of motherhood, such a body is manipulated, shaped and trained to obey and respond. Through power exercised within the institution of motherhood, womanhood then becomes a contested terrain of power and subjugation. 


\section{Re-reading Luke 1:36-38}

Moffat translates the encounter between the Angel Gabriel and Mary as follows:

1611 King James Version

36 And, behold, thy cousin Elisabeth, she hath also conceived a son in her old age: and this is the 6th month with her, who was called barren.

37 For with God nothing shall be impossible.

38 And Mary said, Behold the handmaid of the Lord; be it unto me according to thy word. And the angel departed from her.

The dialogue between the angel and Mary illustrates the imperial gaze within the religio-cultural practices of ancient Israel. In the story, the angel categorises Elizabeth as barren. The barrenness of Elizabeth is linked with an entry into motherhood. It is with the entry into motherhood that she ceases to be barren. Barrenness as an institutional stigma is contrasted with motherhood. In other words, the divine opens Elizabeth's womb.

The opening of the womb in the text, I would argue, is aimed at contrasting wifehood and motherhood, as Elizabeth does no longer occupy the status of a wife; her pregnancy legitimates her status into the institution of motherhood. Motherhood is linked to pregnancy and childbearing.

The aim of the article is to attempt to re-read the text from the cultural world view of the Batswana. In the above narrative, the problem of barrenness is resolved by an act of divine intervention. In contrast to the biblical narrative that mythologises the birth prophecies, the Batswana have a pragmatic response to the issue of childlessness. According to the Batswana, a woman who is childless is labelled as moopa. It is important to note that such labelling contains cultural prejudices, as no name is given to a man who cannot produce children. Furthermore, the wife always carries the burden of the lack of offspring in the household.

An identifiable resemblance between the cultural location of the text and that of the Batswana is that women experience barrenness, and men seemingly do not. The biblical narratives do not present us with a male character who experiences barrenness.

The Setswana cultural practice of dealing with the problem of infertility applies the mechanisms to both men and women. Firstly, these mechanisms are to be understood within the cultural practices of marriage.

Mothoagae (2015) argues that the idea of divorce in the marriage practice was farfetched. As marriage ceremonies did not only bring the couple together, but they were also bringing the two families together. It is because the most important people in the rite of marriage are rakgadi [aunt from the paternal side] and malome [uncle from the maternal side] of both families. They are there to journey with and advise the couple. Marriage for the Batswana is twofold, namely to bring the two families together and ensure continued lineage. The fruit of the couple is the bringing forth of offspring.

The pressure is on the wife to produce children; it is the bringing forth of children that grants her an entry into the institution of motherhood. There are similarities between the ancient Israelite practices and that of the Batswana. The production of offspring gives access to both the father and mother into the space of parenthood. It is in such a space that their individual names cease to be and they are referred to by the name of the firstborn child. I would argue that the naming of both parents indicates the politics of parenthood.

Above all, the wife gains recognition and status with her in-laws. Failure to bear children comes with stigmatisation. Generally, women will be the first to be stigmatised and labelled as moopa [barren].

Tradition has devised a solution to address the question of barrenness.

Prior to the implementation of the prescriptions of tradition, the rakgadi [aunt from his paternal side] of the husband will engage the husband to ascertain why there has not been any sign of a baby. This will be generally performed a year after their marriage. If the husband responds by stating that keitayalefika, mmelefikaga le tswemetsi [I am hitting the rock and the rock does not produce water], it will be an indication to the family that he has been trying but nothing is happening. At times, this could be necessitated by the fact that the husband has performed what is referred to as thobelasegotlho [having a child with someone else, while married].

It is at this point that the maternal family of the wife will be informed about the situation. They will then take their daughter and consult with the diviner-healer to ascertain the problem. If the wife were found to be a moopa, the family would consult with her in-laws to trigger the prescription of the tradition, namely that the practice of thutafatsadirope [heating or warming up the thighs] would be effected. According to the practice, the two families agree that the younger sister will be sent to help her sister and bear children for her.

These children would be regarded as her children. Through her sister, the childless woman then becomes the mother of these children. This also speaks to the idea that your children are never your own, as mamogolo or mmangwane [aunt], you are the mother of your sister's children.

\section{Emerging tensions between cultural and imperial gaze}

The article locates itself within the Setswana practices and the first translation of the Bible into Setswana by Robert Moffat. It is aimed at reflecting on the translation of the word and how meaning and practices of such a status could have 
been understood by the receptor culture. In other words, how the use of a particular word may have a particular meaning and how it would be culturally be treated or responded to.

The story of Elizabeth and the Setswana cultural practices highlight the tensions between the biblical text and the receptor culture. In the biblical text, the condition of childlessness comes to end with the pregnancy of Elizabeth. While in the receptor culture, childlessness is mitigated by a cultural practice of go thutafatsadirope. The cultural practice within the receptor culture takes a pragmatic approach to the question of childlessness, while in the biblical text, prayer and belief in the divine lead to the end of the condition of barrenness. In other words, the text suggests that the intervention from the divine, the pregnancy and the birth brings with it the end to the stigma of barrenness.

Oduyoye in her article (1999) brings the tensions between the two pillars head to head. She contrasts her own West African tradition or response to the question of childlessness and that of the early church. The aim for Oduyoye is to indicate the change in perspective from the Christians in the early church. Persuaded that the 'end times' were imminent, the early church expected Jesus at any moment and was not 'preoccupied with biological fruitfulness' but was instead focused on bringing forth 'the fruits of the Spirit in the faith community and in the life of the individual Christian' (1999:115-116).

Reflecting on her own status as a childless woman, she describes the West African traditional wedding ceremonies that proceed with a 'basic assumption within the whole of the marriage transaction' of 'fruitfulness [in childbirth]' (1999:115-116). She details the lack of 'no empowering word and no ceremony to strengthen what may, for many reasons, turn out to be a childless marriage' and how the 'general taunting of the community is reflected in sermons from our pulpits' (1999:116).

Her reflection challenges the church to find stories to strengthen and encourage the childless, as this is a real challenge facing the church of every age. Such an approach would make its ministry relevant to the lives of its community. I agree with this assertion by Oduyoye, precisely because Christianity does seem to lack a sufficient repertoire of stories from which the childless can be strengthened. Furthermore, biblical narratives on the birth prophecies indicate that barrenness is eradicated with the birth of a boy child. What is also worth reflecting on is that in these birth prophecies women do not give birth to a girl child. In other words, the birth of boy child sustains and maintains the patriarchal gaze that giving birth to a boy child not only does it maintain such a system, it is also linked with the economical heritage that comes after the passing of the head of the household. Oduyoye argues that on the contrary there are women that continue to live the experience of patriarchal gaze due to the persistence of the condition of barrenness. The patriarchal gaze through disciplinary power has plasticized and constructed Motherhood as a system of power. Nnaemeka (1997) argues that politics of motherhood, the experiences that come with mothering, are connected to the dynamics of power and knowledge production. She states:

At the center of the myriad of issues thus raised - history, memory, wisdom, knowledge, etc. - is the old woman (mother/ grandmother); the old woman as storyteller/historian. Because gendered knowledges are also located knowledges, the old woman's interlocutors (the males, in particular) hear not the knowledge-in-wisdom in her narrative but the silly and nonsensical sounds of the periphery. (p. 8)

Oduyoye's reflection on the question of childlessness, the Setswana cultural practice of go thutafatsadirope as well as the available literature expose us to the paradoxes and the opposing views. These paradoxes and opposing views expose the intricacies of womanhood in African literature, while at the same time recognising the ambiguities' inherent in the images of women in African literature. This includes images such as objectified, central or marginal, powerful or powerless, passive or active and victim or agent. These images draw attention to the sexual and cultural politics that construct the institution of motherhood in patriarchy as divergent to the actual experiencing of motherhood (mothering) by women.

\section{Call for the decolonisation of the institution of motherhood and womanhood}

African women literature has been attempting to decolonise and de-patriachalise the institution of motherhood. Such a move towards decolonisation is based on the argument that motherhood is an experience rather than a patriarchal institution. Put differently, they place the focus on the experience of women, rather than the demands and the surveillance performed by a patriarchal system. Nnaemeka (1997) makes an argument for a distinction between motherhood as an institution and motherhood as an experience. She further states that patriarchy constructs the institution of motherhood while women experience it. Nnaemeka (1997) makes the following remarks regarding the hostility of the institution of motherhood:

Motherhood is dangerous to women because it continues the structure within which females must be women and mothers and, conversely, because it denies to females the creation of a subjectivity and world that is open and free. An active rejection of motherhood entails the development and enactment of a philosophy of evacuation. Identification and analysis of the multiple aspects of motherhood not only show what is wrong with motherhood, but also the way out. A philosophy of evacuation proposes women's collective removal of themselves from all forms of motherhood. (p. 5)

Freedom is never achieved by the mere inversion of an oppressive construct, that is, by seeing motherhood in a 'new' light. Freedom is achieved when an oppressive construct, motherhood, is vacated by its members and thereby rendered null and void. (p. 5) 
According to Nnaemeka, the burden of motherhood and victimhood continues to be a central feature of feminist discourse on motherhood. Contrary to the mainstream feminist discourse on motherhood, literature by African women endeavours to delink motherhood and victimhood, similar to the manner in which they distinct wifehood from motherhood. The works of Bâ (1989) and Emecheta (1979) make an argument for motherhood as an experience ('mothering') with its pains and rewards rather than motherhood as a patriarchal institution. Accordingly, motherhood is discussed in relative terms that reflect different personal histories. These texts offer a human face to motherhood. It is not astonishing then that in spite of the pains of motherhood, most mothers in the texts are not prepared to relinquish it precisely because they know that they are also the recipients of the rewards of mothering.

The Setswana traditional practice though intended to mitigate the problem of childlessness also necessitates the ontological victimisation of childless women. Similarly, the reflection by Oduyoye is symptomatic of how religion and tradition can reduce women to victims of a patriarchal system. The biblical narratives of birth prophecy in Luke 1:36-38 are not immune to the ontological victimisation of childless women precisely because of the link between fertility as a blessing and infertility as a curse. Ibrahim (1997) argues that the move to adopt is indicative of the woman's eagerness to 'mother' while rejecting the abuses (physical, sexual, emotional, etc.) of the institution of motherhood under patriarchy. She remarks (Ibrahim 1997):

Victimhood takes on a different aspect when we examine Mira Masi in Anita Desai's A Clear Light of Day, or the protagonists in Buchi Emecheta's, The Joys of Motherhood or even her first novel, In the Ditch. Here victimhood is tied to motherhood. Desai's Mira Masi resists in the only way she can; she escapes being sexually exploited. In a different way from Firdaus, she passively resists the advances of the younger men in the family by making herself totally 'unappetizing'. Feminists, in turn, must respect that silent resistance without valorizing it. Even given general criteria for productive work, we know that Mira Masi gets herself out of her husband's family's house albeit into a situation in which she is no longer needed and lives to 'become herself'. She becomes the mother of four children whom she does not birth but is 'mother' to, and who end up being very devoted to her in different ways. It is out of this power that she has never had before that she lives out her thus far veiled inner life of fears. It is true that her resistance has been bare, generally against silence/death and alienation from love and human interaction. (p. 155)

Renée (1997) reflects on the reconstruction of motherhood as a form of decolonising motherhood as an institution of power. Larrier reflects on the character of she argues that her choice of profession, namely that of being a midwife, provided her the space of motherhood, thus redefining the understanding of motherhood. She further maintains that this is similar to AndréeBlouin who thought that her political activism performed the same strategy of de-patriarchalising motherhood as the space for masculinist gaze (Renée 1997:198-199).

\section{Conclusion: An empty calabash}

The gospel of Luke like many other biblical texts on barrenness presents us with female experiences on the one hand and the power dynamics of patriarchy within gender on the other hand. The exclusion from the status of motherhood looms large in the stories. On the one hand, women face various societal pressures to fulfil expectations of motherhood. On the other hand, women throughout time face scores of different obstacles that stand in the way of successfully fulfilling these expectations. Women seem to be trapped between a rock and a very hard place. Christianity seems to lack a sufficient repertoire of stories in which many women, in a variety of tight circumstances, can find strength. In other words, the Bible as a document of faith, the word of God, resembles a leaking calabash, as it does not quench the thirst of women who remain childless.

Instead, through the birth prophecies, the Bible institutionalises the masculinist gaze over the reproductive ability of women. Furthermore, biblical discourse on men suffering from childlessness is absent.

One thing that is observable about the birth-prophecy stories is that they discuss the theme of barrenness. The status of childlessness in these narratives portrays the struggles of women such as the mother of Samson, who was accused of barrenness (Jdg 13:3). This includes the struggles against barrenness by women such as Hannah (1 Sm 3-5) and Elizabeth (Lk 1:36). All these women were married but their husbands do not suffer the same fate.

The intervention in these stories comes with the agency of God. It is God, on hearing their prayers, who opens their wombs, and subdues their oppressors. The agency of God is seen through the birth of children to accomplish political objectives. The status of barrenness in the biblical narratives is universally conquered in these birth-prophecy stories. At the same time, the text normalises the stigmatisation of being a childless woman as well as perpetuating cultural prejudice towards women.

It follows then that in both instances (biblical narratives and Setswana cultural practices), the patriarchal gaze upon the female body is upheld and perpetuated by turning a barren woman into a mother. On the contrary, as I have indicated in the previous section, within the Setswana cultural practices, there is a cultural prejudice towards women, as they are the only ones who are referred to as moopa [barren], while such a designation is not ascribed to men. The pragmatic intervention to address the question of a childless marriage with the practice of thutafatsadirope [warm the thighs] affords the barren woman access to the status of motherhood, while remaining barren. It is in both the oral traditional practices and the biblical narratives that we see the dichotomy, while real-life stories depict a different reality. The African women literature aims at exploring the various mechanisms used by women to liberate themselves from the patriarchal gaze. Furthermore, Oduyoye in her article addresses the lack 
thereof that women such as herself can find comfort neither in the Bible nor in their cultural practices. As being barren stigmatises when even in a case of personal choice particularly within the context of marriage. At the same time, Western medicine has advanced in such a way that women who are labelled barren can either be given an opportunity to bear children through medicinal treatment such as IVF (in vitro fertilisation). Others have an opportunity to have access to surrogacy or adoption. It is essential to point out that all of these processes come at a cost. Such a cost has to also include cultural frown on the process. The article argued that motherhood is a system within the patriarchal gaze, and as such not everyone gets to enter that space because labelling and stigmatisation form part of the characteristics of a system that performs disciplinary power over the bodies of women.

The Bible then becomes an empty calabash. The image of the Bible as an empty calabash can be witnessed in Oduyoye's reflection on the status of a childless woman. In this article, Oduyoye (1999:115) reflects on her own experience as a 'childless woman in the West African space'. She argues that the biblical discourse provides us with several stories about women who have passed through barrenness en route to motherhood. She argues that the Bible's recounting of 'notable patriarchal, priestly, and prophetic names [that] refer to the sons of women who passed through the agonies of childlessness to have baby boys such as Isaac, Samuel, and John the Baptizer' (Oduyoye 1999:115). She notes the silence of the Bible on the topic of childless women who remain childless notwithstanding equally zealous prayers as those of women like Hannah. She writes (Oduyoye 1999):

A worse shame is that Christianity does not seem to have stories from which the childless can draw strength. If there are such stories, we must find them, for the sake of many who suffer in silence. (pp. 115-116)

\section{Acknowledgements}

I would like to thank the support of my family. The University of South Africa, College of Human Sciences for affording me the space and time to do research.

\section{Competing interests}

The author has declared that no competing interests exist.

\section{Author(s) contributions}

I declare that I am the sole author of this research article.

\section{Ethical considerations}

This article followed all ethical standards for a research without direct contact with human or animal subjects.

\section{Funding information}

This research received no specific grant from any funding agency in the public, commercial or not-for-profit sectors.

\section{Data availability statement}

Data sharing is not applicable to this article as new data were created or analysed in this study.

\section{Disclaimer}

The views and opinions expressed in this article are those of the author and do not necessarily reflect the official policy or position of any affiliated agency of the author.

\section{References}

Achebe, C., 1987, Anthills of the Savannah, Doubleday, New York.

Bâ, M., 1989, So long a letter, transl. M. Bodé-Thomas, Heinemann, London.

Dasen, V., 2001, 'Childbirth and infancy in Greek and Roman antiquity', in B. Rawson (ed.), A companion to families in the Greek and Roman worlds, pp. 291-314, Wiley-Blackwell, Oxford.

Emecheta, B., 1979, The joys of motherhood, Braziller, New York.

Evangeliakotsamahuku a molemo a kuariloengki Luka, 1830, Lattakoo (Dithakong/ Kuruman, Northern Cape), Bechuana Mission, The Gospel of Luke, transl. R. Moffat.

Foucault, M., 1978, The history of sexuality, Pantheon Books, New York.

Foucault, M., 1991, Discipline and Punish: The birth of the prison, Penguin, London.

Ibrahim, H., 1997, 'Ontological victimhood: "Other" bodies in madness and exile toward a Third World feminist epistemology', in O. Nnaemeka (ed.), The politics of $(m)$ othering womanhood, identity, and resistance in African literature, pp. 148-162, Routledge, London.

Mothoagae, I.D., 2015, 'Setswana proverbs within the institution of lenyalo [marriage]: A critical engagement with the bosadi [womanhood] approach', Verbum et Ecclesia 36(1), Art. \#1403, 1-7. https://doi.org/10.4102/ve.v36i1.1403

Nnaemeka, O., 1997, The politics of (m)othering womanhood, identity, and resistance in African literature, Routledge, New York.

Oduyoye, M.A., 1999, 'A coming home to myself: The childless woman in the West African space', in M.A. Farley \& S. Jones (eds.), Liberating eschatology: Essays in honor of Letty M. Russell, pp. 105-120, Westminster John Knox Press, Louisville, KY.

Renée, L., 1997, 'Reconstructing motherhood: Francophone African women auto biographers', in O. Nnaemeka (ed.), The politics of (m)othering womanhood, identity, and resistance in African literature, pp. 193-206, Routledge, London.

Roymans, N., 2009, 'Hercules and the construction of a Batavian identity in the context of the Roman empire', in T. Derks \& N. Roymans (eds.), Ethnic constructs in antiquity: The role of power and tradition, pp. 219-238, Amsterdam University Press, Amsterdam.

Silk, M., 1985, 'Heracles and Greek Tragedy', Greece and Rome 32(1), 1-22. https:// doi.org/10.1017/\$0017383500030096

Skeggs, B., 2002, Formations of class and gender becoming respectable, Sage, London. The King James Version, 1611, Logos research systems, Samuel Bagster and Sons, London.

Wire, A.C., 2005, 'Women's history from birth-prophecy stories', in R.A. Horsley (ed.), A people's history of Christianity, vol. 1, pp. 71-93, Fortress Press, Minneapolis, MN. 